\title{
Contents of nutrients and dietary fibre in wild and cultivated mushrooms
}

\author{
MATTI KREULA, MAIJA SAARIVIRTA and SIRKKA-LIISA KARANKO
}

\begin{abstract}
KREULA, M., SAARIVIRTA, M. \& KARANKO, S-L. 1978: Contents of nutrients and dietary fibre in wild and cultivated mushrooms. - Karstenia 18 (suppl.).

The basic composition and the contents of amino acids and fatty acids and eight minerals of 13 wild and 2 cultivated mushrooms and the content of dietary fiber were estimated. On a dry matter basis, the protein content of the mushrooms studied (total $\mathrm{N} \times 6.25$ ) was $12 \%-35 \%$, the lipid content $1.2 \%-8.9 \%$, and the ash content $6 \%-13 \%$. The total essential amino acid content (excluding Try) was $2.6 \%-8.2 \%$ of the dry matter.

The fatty acid composition of mushrooms resembled the general composition of vegetable fats, the major components being oleic acid and linoleic acid.

The mineral composition was complex; it seems that mushrooms are good sources of $\mathrm{Cu}$ and fairly good sources of $\mathrm{Zn}$ as compared with other foodstuffs, provided that the avalland fairly good sources of $\mathrm{Zn}$ as compar
ability of those minerals is normal.

The mean content of dietary fibre in mushrooms was $29 \%(13-39$ \%), which is much higher than the crude fibre content usually given in food composition tables. Mushrooms seem to be a fairly good source of diatery fibre.
\end{abstract}

M. Kreula, M. Saarivirta \& S-L. Karanko, Laboratory of the Foundation for Chemical Research, Kalevankatu 56 B, SF-00180 Helsinki 18, Finland.

I. Contents of amino acids, fatty acids and minerals in 13 wild and 2 cultivated mushroom species

The methods used were described in an earlier publication (Kreula et al. 1976), together with data obtained for'll mushroom species. The species included in the study here reported were: Boletus edutis, Albatrellus ovinus, Ramaria flava, Gyromitra esculenta, Craterellus cornucopioides, Cantharellus cibarius, C. tubaeformis, Armillariella mellea, Coprinus comatus, Leccinum versipelle, Lactarius rufus, L. trivialis, L. torminosus, Flammulina velutipes and Pleurotus ostreatus. The last two species were cultivated in the laboratory.

For the sake of clarity the results obtained for 5 of the species and the mean values for all 15 mushroom species are presented in Tables 1-4.

In Table 1 the basic composition of the mushrooms and that of potato tubers (Souci et al. 1969) are given. The mean contents of protein, fat and ash in the 15 mushroom species were $23 \%$ (12-35\%), $4.5 \%$ $(2-9 \%)$ and $8.5 \%(5-13 \%)$, respectively, on a dry matter basis. Compared with mushrooms potato contains less protein and fat but the ash content is similar.

Table 2 shows the contents of essential amino acids, excluding tryptophan as it was not determined in this study, in the mushrooms. For comparison, mean values of data given by Souci et al. (1969) for mushrooms and potato are included.

The total amounts of essential amino acids in mushrooms varied from 3 to $8 \%$, the mean being $5.3 \%$ on a dry matter basis. The content of methionine was the lowest of all. In the various mushroom species the contents of individual amino acids varied conside- rably; for example the lysine content from 0.4 to $1.5 \%$ and the leucine content from 0.6 to $1.8 \%$. Our data and those obtained from the literature were quite similar. As compared with mushrooms, the contents of essential amino acids in potato are somewhat low. Table 3 shows the fatty acid composition in the mushrooms. For comparison, data for potato tubers (Lepage 1968) and mushrooms (Shaw 1967) are given. The fatty acid composition of mushrooms varied considerably, but resembled the general composition of vegetable fats in that the amounts of oleic and linoleic acids were comparatively large: the average figure for oleic acid was $30 \%(3-51 \%)$ and for linoleic acid $41 \%$ (13-84\%) of the total amounts of fatty acids. The results are in agreement with those obtained by Shaw (1967). The fatty acid composition of mushrooms resembled that of potato except that in potato the oleic acid content was low and the linolenic acid content high.

The composition of the lipid in mushrooms is not of much significance from a nutritional point of view since their lipid content on a wet reight basis is only $0.2-0.5 \%$.

Table 4 gives the contents of minerals in the mushrooms. For comparison, corresponding data for potato (Souci et al. 1969) and mushrooms (Hinneri 1975, Kurkela 1972, Sassi 1976) are given.

The mineral contents in the mushrooms were very much the same as those given in the literature. When comparing the contents of minerals in potato with those in mushrooms it is observed that there are no essential differences in magnesium, sodium, potassium and iron. The content of calcium in potato is somewhat higher 
than in mushrooms, but the contents of manganese, copper and zinc are much lower than in mushrooms. There were wide variations in the contents of minerals in the 15 mushroom species: for example, copper varied from 4 to $85 \mathrm{mg} / \mathrm{kg}$ and manganese from 8 to $72 \mathrm{mg} / \mathrm{kg}$.

It. seems that mushrooms are good sources of $\mathrm{Cu}$ and fairly good sources of $\mathrm{Zn}$ provided that their availability is not notably different from that in other foodstuffs. It was noted earlier that the general composition of cultivated mushrooms did not differ essentially from that of wild mushrooms (Kreula et al. 1976).
Table 1. Basic composition of certain mushroom species

\begin{tabular}{|lccr|}
\hline & Protein & Fat & Ash \\
\cline { 2 - 4 } & \multicolumn{3}{c|}{ \% of d.m. } \\
\hline Boletus edulis & 22 & 1.7 & 6.2 \\
Gyromitra esculenta & 31 & 3.4 & 10.2 \\
Cantharellus cibarius & 17 & 3.9 & 12.8 \\
Lactarius torminosus & 28 & 7.2 & 6.7 \\
Pleurotus ostreatus & 22 & 2.6 & 8.4 \\
Mean of 15 mushroom & 23 & 4.5 & 8.5 \\
species & & & \\
Potato tubers (Souci et al.1969) & 9 & 0.7 & 6 \\
\hline
\end{tabular}

Table 2. Contents of essential amino acids ( $\%$ of dry matter) in certain mushroom species. Tryptophan was not determined

\begin{tabular}{|lcccccccc|}
\hline Species & Ile & Leu & Val & Met & Phe & Thr & Lys & Total \\
\hline Boletus edulis & 0.9 & 0.9 & 0.7 & 0.4 & 0.5 & 0.6 & 0.8 & 4.8 \\
Gyromitra esculenta & 1.1 & 1.6 & 1.4 & + & 1.1 & 1.0 & 1.4 & 7.6 \\
Cantharellus cibarius & 0.5 & 0.8 & 0.6 & 0 & 0.5 & 0.5 & 0.7 & 3.6 \\
Lactarius torminosus & 0.8 & 1.5 & 1.1 & 0.3 & 1.0 & 1.2 & 1.1 & 7.2 \\
Pleurotus ostreatus & 0.9 & 1.4 & 1.0 & 0.3 & 0.9 & 0.9 & 1.5 & 6.9 \\
Mean of 15 mushrocms & 0.7 & 1.1 & 0.8 & 0.2 & 0.7 & 0.8 & 0.9 & 5.3 \\
Mushrooms (Souci et al. 1969) & 0.5 & 1.1 & 0.7 & 0.1 & 0.7 & 0.8 & 0.9 & 4.8 \\
Potato & 0.5 & 0.6 & 0.5 & 0.2 & 0.4 & 0.4 & 0.5 & 3.1 \\
\hline
\end{tabular}

Table 3. Fatty acid composition ( $\% / \mathrm{w} / \mathrm{w}$ ) of certain mushroom species

\begin{tabular}{|c|c|c|c|c|c|c|c|}
\hline Species & $\mathrm{C}_{10: 0-17: 1}$ & $c_{16: 0}$ & $C_{18: 0}$ & $\mathrm{c}_{18: 1}$ & $C_{18: 2}$ & $c_{18: 3}$ & $C_{20: 0-24: 0}$ \\
\hline Boletus edulis & 3.5 & 10.2 & 0.9 & 15.1 & 62.6 & 6.1 & 4.6 \\
\hline Gyromitra esculenta & 3.9 & 13.1 & - & 8.1 & 72.9 & 0.5 & 1.6 \\
\hline Cantharezlus cibarius & 4.8 & 9.1 & 3.8 & 41.2 & 37.0 & 1.2 & 3.0 \\
\hline Lactarius torminosus & 1.4 & 2.8 & 53.2 & 18.7 & 21.6 & 0.5 & 1.7 \\
\hline Pleurotus ostreatus & 2.7 & 14.3 & 1.7 & 14.8 & 60.6 & 0.7 & 5.1 \\
\hline Mean of 15 mushrooms & 3.9 & 8.8 & 5.9 & 30.3 & 41.3 & 1.3 & 8.8 \\
\hline Mushrooms (Shaw 1967) & 3.8 & 15.8 & 7.7 & 25.1 & 48.5 & & \\
\hline Potato (Lepage 1968) & - & 18.7 & 4.3 & 0.7 & 47.7 & 28.5 & \\
\hline
\end{tabular}

Table 4. Contents of minerals in certain mushroom species

\begin{tabular}{|c|c|c|c|c|c|c|c|c|}
\hline \multirow[t]{2}{*}{ Species } & $\mathrm{Ca}$ & $\mathrm{Fe}$ & $\mathrm{Mn}$ & $\mathrm{Zn}$ & $\mathrm{Cu}$ & $\mathrm{Mg}$ & $\mathrm{Na}$ & K \\
\hline & \multicolumn{5}{|c|}{$\mathrm{mg} / \mathrm{kg}$ d.m. } & \multicolumn{3}{|c|}{$\mathrm{g} / \mathrm{kg}$ d.m. } \\
\hline Boletus edulis & 150 & 74 & 16 & 66 & 25 & 0.5 & 0.9 & 26 \\
\hline Gyromitra esculenta & 120 & 140 & 26 & 110 & 85 & 1.0 & 0.8 & 44 \\
\hline Cantharellus cibarius & 220 & 93 & 29 & 110 & 46 & 1.1 & 0.6 & 53 \\
\hline Lactarius torminosus & 306 & 61 & 10 & 142 & 22 & 1.3 & 0.4 & 27 \\
\hline Pleurotus ostreatus & 159 & 147 & 13 & 170 & 25 & 2.7 & 0.4 & 49 \\
\hline Mean of 15 mushrooms & 223 & 95 & 25 & 92 & 34 & 1.2 & 0.6 & 37 \\
\hline $\begin{array}{l}\text { Mushrooms (Hinneri 1975, } \\
\text { Kurkela 1972, Sassi 1976) }\end{array}$ & 367 & 64 & 17 & 117 & 37 & 0.9 & & \\
\hline Potato (Souci et al. 1969) & 591 & 41 & 7 & 1 & 7 & 1.5 & 0.9 & 24 \\
\hline
\end{tabular}


II. Contents of dietary fibre in 11 mushroom species

Recently there has been growing interest in the "true" content of fibre in foods. Therefore we made a preliminary study of the contents of dietary fibre in mushrooms. We used the method of Elchazly \& Thomas (1976), which measures water-insoluble dietary fibre, as follows. Dry mushroom powder was extracted with petroleum-ether and the fat-free material was autoclaved for $1 \mathrm{~h}$ and digested first with the enzyme takadiastase and then with trypsin. After centrifugation the residue was washed successively with $\mathrm{HCl}$, water, ethanol, acetone and ether. The oven-dried residue was weighed, ashed, and the weight of the ash substracted from that of the residue. For comparison, the contents of dietary and crude fibre (Valtion matalouskemian laitos 1967) in wheat brah and carrot were also estimated. The composition of dietary fibre was not determined in this study.

The mushrooms in this study were: Agaricus sp., C. cibarius, C. comatus, G. esculenta, Kuehneromyces mutabilis, Lactarius rufus, L. thejogalus, L. torminosus, Lecoinum versipelle, Russula flava and $P$. ostreatus. The mushrooms were of different ages but all were fit to eat.

Table 5 shows the contents of water-insoluble diatery fibre and crude fibre in mushrooms, wheat bran and carrot.

The dietary fibre content in mushrooms varied from 13 to $39 \%$, the mean value being $29 \%$, contents in wheat bran and carrot were $30 \%$ and $10 \%$ respectively. In mushrooms and bran the contents of crude fibre were markedly lower than those of dietary fibre, whereas the difference between crude and dietary fibre contents in carrot was small.

Elchazly \& Thomas (1976) found dietary fibre

Table 5. Content of dietary fibre and crube fibre in certain mushroom species

\begin{tabular}{|c|c|c|}
\hline \multirow[t]{2}{*}{ Species } & Dietary & Crude fibre \\
\hline & \multicolumn{2}{|c|}{ \% of d.m. } \\
\hline Agaricus species & 19 & $4.7^{*}$ \\
\hline Canthareltus cibarius & 39 & $11.2^{\mathrm{x}}$ \\
\hline Corpinus comatus & 13 & \\
\hline Gyromitra esculenta & 26 & $2.7^{*}$ \\
\hline Kuehneromyces mutabilis & 29 & \\
\hline Lactarius rufus & 29 & 7.8 \\
\hline L. thejogalus & 34 & \\
\hline L. torminosus & 32 & \\
\hline Leccinum versipelle & 33 & $5.2^{\mathrm{X}}$ \\
\hline Russula flava & 38 & \\
\hline Pleurotus ostreatus I & 22 & \\
\hline P. ostreatus II & 34 & \\
\hline Mean value & 29 & 6.3 \\
\hline Wheat bran & 30 & 10.5 \\
\hline Carrot & 10 & 7.4 \\
\hline
\end{tabular}

${ }^{*}$ Souci et al. 1969 contents of $12.2 \%$ in carrot, $6.6 \%$ in potato and $17.1 \%$ in cabbage; the corresponding contents of crude fibre were $8.3,1.8$ and $12.8 \%$.

Our results and those of other investigators (e.g. Elchazly \& Thomas 1976, Trowell 1976, Asp et al. 1977) show that crude fibre contents given in food composition tables are erroneously low and do not represent the "true" content of fibre in foods. Dietary fibre is not a chemical entity but a mixture of several types of polysaccharide and lignin. Its composition and physical properties vary with the food in question. Therefore no single method can be regarded as adequate for all types of food.

The contents of water-insoluble dietary fibre in mushrooms reported here were obtained by the enzymatic method of Elchazly \& Thomas (1976) and may differ from data obtained with other methods. However, they provide a basis for the calculation of intakes of dietary fibre from common mushrooms.

\section{Acknowledgement}

We thank Mr Kari Nurmela for selection of the dietary fibre method and for performing the fibre analyses.

\section{References}

Asp, N-G., Dahlqvist, A. \& Johansson, C-G. 1977: Assessment of digestible carbohydrate and dietary fibre content of food with the duplicate portion technique. - Forsta Nordiska Konferensen i Năringslära, 94.

Elchazly, M. \& Thomas, B. 1976: Über eine biochemische Methode zum Bestimmen der Ballaststoffe und ihrer Komponenten in pflanzlichen Lebensmitteln. - z. Lebensm. Unters. Forsch. 162: 329-340.

Hinneri, S. 1975: Mineral elements of macrofungi in oak-rich forests on Lenholm Island, inner archipelago of SW Finland. - Ann. Bot. Fennici 12: 135-140.

Kreula, M., Saarivirta, M. \& Karanko, S-L. 1976: On the composition of nutrients in wild and cultivated mushrooms. - Karstenia 16: 10-14.

Kurkela, R. 1972: Metsäsienet - haaste maamme elintarviketeollisuudelle ja ravintotutkimukselle. Kemian Teollisuus 11: 825-829.

Lepage, M. 1968: The lipid components of white potato tubers (Solanum tuberosum), - Lipids 3: 477-481.

Sassi, S. 1976: pers. comm.

Shaw, R. 1967: Fatty acid of fruiting bodies of Basidiomycetes. - Nature 213: 86-87.

Souci, S.W., Fachmann, W. \& Kraut, H. 1969: Die Zusammensetzung der Lebensmittel. II. - Wissenschaftliche Verlagsgesellschaft M.B.H. Stuttgart.

Trowe11, H. 1976: Definition of dietary fibre and hypotheses that it is a protective factor in certain diseases. - Am. J. Clin. Nutr. 29: 417427.

Valtion matalouskemian laitos (State Institute of Agricultural Chemistry) 1967: Tutkimusmenetelmat I, Weenden menetelmän sovellutus. - B 3.3. 